\title{
A Cost Effective Strategy for Production of Bio-surfactant from Locally Isolated Penicillium chrysogenum SNP5 and Its Applications
}

Gunjan Gautam, Vishwas Mishra, Payal Verma, Ajay Kumar Pandey and Sangeeta Negi*

Department of Biotechnology, Motilal Nehru National Institute of Technology, Allahabad, India

\begin{abstract}
The current work is enlightened about a cost effective bioprocess using one factor at a time approach for the production of bio-surfactant through solid state fermentation. A fungal strain Penicillium chrysogenum SNP5 isolated from grease contaminated soil was reconnoitered for the production of bio-surfactant. Various physiochemical parameters i.e., substrate composition, nitrogen supplements, extraction media and $\mathrm{pH}$ were optimized in order to optimized the production in terms of emulsification index and oil displacement assay. Maximum oil displacement area produced using grease waste and wheat bran $(1: 1 \mathrm{w} / \mathrm{w})$, waste cooking oil and wheat bran $(1: 1 \mathrm{v} / \mathrm{w})$ as a substrate were $3.5 \mathrm{~cm}$ and 5 $\mathrm{cm}$, respectively. Whereas, considered values for emulsification activity with oil and diesel were $43 \%$ and $22 \%$ during optimization of substrate composition. Variable ratios of grease waste and wheat bran were capable to enhance the emulsification activity with oil and diesel up to $45 \%$ and $24 \%$ in presence of grease and wheat bran (1.5:1). The strain also showed enhancement of emulsification activity $45 \%$ and $23 \%$ with oil and diesel respectively to utilized yeast extract as a nitrogen source and the highest emulsification activity $38 \%$ in diesel, $47 \%$ in oil and oil displacement $5.5 \mathrm{~cm}$ was found at $\mathrm{pH} 8$ with grease and wheat bran as a substrate. Preliminary characterizations by thin layer chromatography showed that the bio-surfactant was lipopeptide in nature and was also confirmed through FTIR analysis. Metabolization of industrial grease waste through solid state fermentation has never been reported before for the production of biosurfactants therefore would be applicable in petroleum and biodiesel industry. The partially purified biosurfactants was further investigated for antimicrobial activity and enhanced oil recovery. It displayed effective zones of inhibition against both gram $+v e(1.67 \mathrm{~cm})$ and gram $-v e(1.93 \mathrm{~cm})$ as well as $16.5 \%$ enhanced recovery of oil. Both results also give a positive support to its role in pharmaceuticals as well as in petroleum and oil industry.
\end{abstract}

Keywords: Biosurfactant; Lipopeptides; Solid state fermentation; FTIR; Production and extraction

\section{Introduction}

Science, mysteries, miracles, inventions and Eureka!" all are required for invigoration of a new approach to develop a product. Biosurfactant (BS) word implies to "A surface active substance which synthesized from microbes to metabolize water insoluble substance such as hydrocarbons and lipids etc". BSs are amphiphilic compounds contain hydrophobic and hydrophilic moieties that reduce surface and interfacial tensions between individual molecules at the surface and interface, respectively. BS are generally characterized as anionic (usually due to sulphonate or sulphur group), cationic (positively charged quaternary ammonium group) and nonionic (lack their ionic constituents). They may be characterized in terms of molecular weight as high mass containing BS (polymeric and particulate surfactants) or low mass BSs (i.e., lipopeptides, glycolipids and phospholipids etc.) [1,2].

Unlike petroleum based surfactant which are usually non biodegradable thus remain toxic to the environment, biosurfactants have many advantages in terms of biodegradability, biocompatibility, digestibility, low toxicity, availability of raw material for production and surface activeness (can lower down surface tension), which allows their application in cosmetic, pharmaceuticals, as functional food additives, agriculture, medicine, petroleum and industry etc.

Due to this increasing awareness on the need to protect the ecosystem and mankind, necessitate an increased interest in surfactants of microbial origin as possible alternatives to chemically synthesized ones $[3,4]$. According to a new market report of transparency market research global market of BSs was worth USD 1,735.5 million in 2011 and is expected to attain USD 2,210.5 million in 2018, growing at a CAGR of 3.5\% from 2011 to 2018 with leading position of European region sharing $53.3 \%$ of global BSs market revenue share [5].
To meet such boost in demand of BS production must be cost effective and at industrial scale. Although scale up process has lacunae due to its high production cost with low rate of production compare to synthetic surfactant. So it is very imperative that our target should be relying on development of successive effort and strategies in such a way that our needs replenish the constancy of nature without any major changes in next generation [6] and environmental sustainability emphasizing, the production of eco-friendly natural bioactive compounds from renewable substrates those have the potential to replace chemically synthesized surfactants [7].

In this concern various microorganisms have been explored for the production of BS and major of studies used submerged fermentation. However, it leads to a main disadvantage of foaming which further has a tendency to accumulate micro-organisms on foam and finally lead to washing out of cells from media. Instead of that, solid state fermentation represents a promising future of production with two main advantages firstly, use of low cost substrate for production and secondly it evades foaming problems $[8,9]$.

The present work is centered on achieving a cost effective and

*Corresponding author: Sangeeta Negi, Assistant Professor, Department of Biotechnology, National Institute of Technology, Allahabad, 211004, India, Tel: 0532227-1240; E-mail: sn5@mnnit.ac.in

Received July 23, 2014; Accepted September 19, 2014; Published September 24,2014

Citation: Gautam G, Mishra V, Verma P, Pandey AK, Negi S (2014) A Cost Effective Strategy for Production of Bio-surfactant from Locally Isolated Penicillium chrysogenum SNP5 and Its Applications. J Bioprocess Biotech 4: 177 doi: $10.4172 / 2155-9821.1000177$

Copyright: (c) 2014 Gautam G, et al. This is an open-access article distributed under the terms of the Creative Commons Attribution License, which permits unrestricted use, distribution, and reproduction in any medium, provided the original author and source are credited. 
optimum amount of BS production by $P$. chrysogenum SNP5 isolated from grease contaminated soil, using one at a time approach to optimize variable features like substrates compositions, nitrogen sources, substrate ratio, solvent system etc. isolated surfactant were identified through thin layer chromatography method and FTIR. In this study grease waste along with wheat bran has been taken as substrate for the production of $\mathrm{BS}$, which acted as stimulator of the synthesis of hydrophobic moiety as well as protein structure of BS, which has been never reported earlier.

\section{Material and Methods}

\section{Organism and maintenance of inoculums}

A fungal strain of Penicillium chrysogenum SNP5 was isolated from soil contaminated grease waste. The strain P. chrysogenum SNP5 was reported as good producer of lipases $\left(46 \mathrm{U} / \mathrm{ml}\right.$ at $\left.30^{\circ} \mathrm{C}\right)$ using Solid State Fermentation (SSF) [10]. The microorganism was maintained on Malt Extract Agar (MEA) slope with $1 \% \mathrm{v} / \mathrm{v}$ glycerol at $4^{\circ} \mathrm{C}$.

\section{Media and inoculum preparation:}

$50 \mathrm{ml}$ Czepek- dox media $\left(\mathrm{NaNO}_{3} 2.5 \mathrm{~g} / \mathrm{l}, \mathrm{KH}_{2} \mathrm{PO}_{4} 1.0 \mathrm{~g} / \mathrm{l}\right.$, $\left.\mathrm{MgSO}_{4} \cdot 7 \mathrm{H}_{2} \mathrm{O} 0.5 \mathrm{~g} / \mathrm{l}, \mathrm{KCl} 0.5 \mathrm{~g} / \mathrm{l}\right)$ supplemented with $1 \%$ glucose and $5 \%$ glycerol as carbon sources incubated with $10^{7}$ spore $/ \mathrm{ml}$ of a culture of $P$. chrysogenum and allowed to grow at $30^{\circ} \mathrm{C}$ for next 5-6 days. The next of $6^{\text {th }}$ day the culture was vortexed for the separation of spores and mycelium. Spores containing mycelium free supernatant was further used as inoculate for production of BSs.

\section{SSF for BSs production:}

The substrate was prepared with wheat bran, grease waste at different ratios and supplemented with Czepek-dox media $\left(\mathrm{NaNO}_{3}\right.$ $\left.2.5 \mathrm{~g} / \mathrm{l}, \mathrm{KH}_{2} \mathrm{PO}_{4} 1.0 \mathrm{~g} / \mathrm{l}, \mathrm{MgSO}_{4} \cdot 7 \mathrm{H}_{2} \mathrm{O} 0.5 \mathrm{~g} / \mathrm{l}, \mathrm{KCl} 0.5 \mathrm{~g} / \mathrm{l}\right)$ in $1: 2(\mathrm{w} / \mathrm{v})$ ratios in $250 \mathrm{ml}$ Erlenmeyer flasks to provide the basic micronutrients. The culture medium was autoclaved at $121^{\circ} \mathrm{C}$ for $20 \mathrm{~min}$. after the sterilization medium was inoculated with $2 \mathrm{ml}$ of spore suspension $\left(10^{7}\right.$ spores $\left./ \mathrm{ml}\right)$ and incubated for 10 days at $30^{\circ} \mathrm{C}$.

\section{Optimization of process parameters:}

The production optimization was regulated in a series of experiments, changing one parameter at a time while keeping other variables constant at a particular set of conditions. Five factors were considered to achieve high production of BSs: the substrate sources (C), nitrogen sources $(\mathrm{N}), \mathrm{C} / \mathrm{N}$ ratio, solvent systems, $\mathrm{pH}$. The substrate sources used were grease waste, waste cooking oil, soyabean oil and oil cake with $\mathrm{NaNO}_{3}$ as a nitrogen source. In case of nitrogen sources $\mathrm{NaNO}_{3}$, yeast extract, peptone and malt extract were used at a concentration of $1 \%$ with optimum carbon source. Variation in $\mathrm{C} / \mathrm{N}$ ratio was applied through changes in optimum carbon sources from 1 , $1.5,2,2.5$ and 3 by keeping constant nitrogen source. $\mathrm{pH}$ ranges were varied from 3-12 for optimization of higher production (Table 1).

\section{Analytical examinations}

Collection of extract: $5 \mathrm{~g}$ of fermented bran were extracted with $1: 3$ ratios of distilled water at $30^{\circ} \mathrm{C}$ followed by extraction with appropriate filtration and centrifugation at 10000 for $10 \mathrm{~min}$ at $4^{\circ} \mathrm{C}$ for the separation of solids and spores. Recovery of BS was expressed in amount of crude extract obtained per gm. of dry substrate (gds) [6].

Determination of Emulsification Index (EI): Emulsification activity was observed with respect of oil and hydrocarbon. By adding

\begin{tabular}{|c|c|c|c|c|c|}
\hline Substrate & $\begin{array}{c}\text { Ratio of } \\
\text { substrate (w/w) }\end{array}$ & $\begin{array}{c}\text { El (oil) } \\
(\%)\end{array}$ & $\begin{array}{c}\text { El( diesel) } \\
(\mathbf{\%})\end{array}$ & ODA(cm) & DCA \\
\hline $\begin{array}{c}\text { Grease waste } \\
\text { wheat bran }\end{array}$ & $1: 1$ & $43 \pm 0.12$ & $22 \pm 0.01$ & $3 \pm 0.15$ & ++ \\
\hline $\begin{array}{c}\text { waste cooking } \\
\text { oil+ wheat bran }\end{array}$ & $1: 1$ & $40 \pm 0.15$ & $20 \pm 0.05$ & $5 \pm 0.90$ & ++ \\
\hline $\begin{array}{c}\text { soybeans oil+ } \\
\text { wheat bran }\end{array}$ & $1: 1$ & $53 \pm 0.20$ & $37 \pm 0.04$ & $5 \pm 0.05$ & +++ \\
\hline $\begin{array}{c}\text { oil cake+ wheat } \\
\text { bran }\end{array}$ & $1: 1$ & $25 \pm 0.62$ & $10 \pm 0.90$ & $2 \pm 0.01$ & + \\
\hline
\end{tabular}

Table 1: Influence of substrate sources for biosurfactant production in terms of $E$ : Emulsification Index; ODA: Oil Displacement Assay; DCA: Drop Collapse Assay; (+: less dispersed drop; ++: moderate dispersed drop; +++ highly dispersed drop of surfactant).

$2 \mathrm{ml}$ of oil or hydrocarbon to the same amount of extract, subjected to vortexed for $2 \mathrm{~min}$ and keeping stand for 24 hours. After 24 hours the emulsification activity was determined by the measurement of percentage of height of emulsified layer $(\mathrm{mm})$ divided by total height of the liquid $(\mathrm{mm})[11]$.

$$
E I=\frac{\text { emulsion height }}{\text { total height }} \times 100 E I=\frac{\text { emulsion height }}{\text { total height }} \times 100
$$

Drop collapse assay: Drop collapse assay depends on destabilization of a liquid on a solid surface due to presence of surfactant. Drop of collected extract was placed on an oil coated glass slide and the destabilization of liquid drop was observed against distilled water used as a control [12].

Oil displacement assay: $40 \mathrm{ml}$ of distilled water was added in 90 $\mathrm{mm}$ petri plate and then $50 \mu \mathrm{l}$ of oil was added on surface to make a thin layer after that it was followed by addition of $10 \mu$ of collected extract on middle of surface. Diameter of displaced oil was observed after $30 \mathrm{sec}$ under visual light $10 \mu \mathrm{l}$ distilled water used as control [13] (Figure 1).

Foam height analysis: $10 \mathrm{ml}$ of collected extract was shacked vigorously for $10 \mathrm{~min}$ to attain a good frothing and left to stand for 2 minutes. Foaming capacity was calculated according to the following equation [14]:

Foaming $=$ emulsion height $/$ total height $\times 100$

\section{Optimization of BS extraction}

For estimation of the most appropriate solvent system for the extraction of BSs: various buffer from range of 3-10 (sodium citrate buffer; 3-6, sodium phosphate buffer; 7-8, sodium carbonate buffer; 9-10 and water) were employed. BS production was further studied with emulsification assay, oil displacement assay and drop collapse assy.

\section{Partial purification of surfactant}

Partial purified extraction of surfactant was done through ethanol precipitation method at $-20^{\circ} \mathrm{C}$ for $16 \mathrm{~h}$. After 16 hour precipitate was collected by centrifugation at $4000 \times \mathrm{g}$ for $15 \mathrm{~min}$ at $4^{\circ} \mathrm{C}$ [15] resulted pellet was treated with hexane to remove excess grease traces and BS was collected in form of pellet after air drying.

\section{Preliminary compositional analysis}

Thin layer chromatography (TLC): A part of crude BS was separated on a TLC Sheet using $\mathrm{CHCl}_{3}: \mathrm{CH}_{3} \mathrm{OH}: \mathrm{H}_{2} \mathrm{O}(65: 25: 4$. v/v/v) 


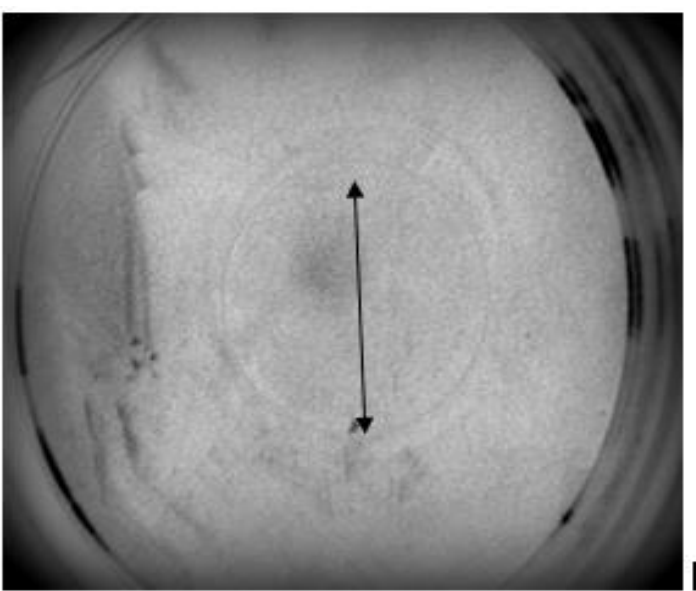

Figure 1: Oil displacement assay. The arrow shows the displaced area of oil (grease and wheat bran ration 1.5:1).

as a solvent system with different color developing reagents. Ninhydrin reagent ( $0.5 \mathrm{~g}$ ninhydrin in $100 \mathrm{ml}$ anhydrous acetone) was used to detect lipo-pepetide kind of BS as a red spot $[16,17]$ and iodine vapors was used to develop lipid moiety of surfactant as a yellow spot.

\section{Structural characterization}

Lowery assay: Presence of protein concentration was assayed by lowery method with the help of standard curve BSA protein [18].

Fourier transform Infra-red spectra analysis: For detection of functional group IR analysis was done by $\mathrm{KBr}$ pellet method, using resolution of $2 \mathrm{~cm}^{-1}$ and $4000-400 \mathrm{~cm}^{-1}$ spectral region [19].

\section{Antimicrobial activity}

Anti microbial activity of partially purified BS evaluated using agar diffusion method. $20 \mathrm{ml}$ Muller Hinton Agar media was prepared each for petri plates on each of which 2 wells were made and were named as $\mathrm{A}$ and $\mathrm{B}$ respectively. The plates were swabbed with $P$. aeruginos $a$ and S. aureus. To the wells $\mathrm{A}, 50 \mu \mathrm{l}$ of partially purified BS was added, to and to the wells B, distilled water (control) was added. The plates were kept in incubation at $37^{\circ} \mathrm{C}$ for 24 hours. The presence of clear zone marked the antimicrobial activity of BS. Three readings of the clear zone diameter were taken for each well and the mean was calculated to determine the actual zone diameter [20].

\section{Application of BS in oil recovery}

To evaluate the efficiency of crude BS produced by $P$. chrysogenum SNP5 in oil recovery process, sand pack column as a laboratory scale technique was employed. A glass column height $17 \mathrm{~cm}$ was packed with $17 \mathrm{~g}$ of acid pretreated sand. The brine solution $(5 \% \mathrm{NaCl}, \mathrm{w} / \mathrm{v})$ was then passed through the column and Pore Volume (PV) was determined by measuring the volume required to make the sand matrix wet in brine solution. After saturating column with brine solution, two stroke engine oil (Honda) was passed through the column until the column got saturated with oil. Once, oil entered in the column, discharge of brine solution was observed from the matrix of sand. The discharged volume of brine from sand pack column was collected and measured to calculate initial oil saturation (Soi). Then again oil saturated column was washed with brine solution until no further oil was discharged in the effluent. The oil retained i.e. residual oil saturation (Sor) after brine solution wash was calculated on the basis of oil loaded and oil discharged in the effluent from column. BSs was then injected and kept it for 24 hours. After 24 hours residual oil was calculated with following equations.

Initial oil saturation $($ Soi \% $)=\frac{O O I P}{P V} \times 100$

Pore volume $(\mathrm{PV})(\mathrm{mL})=$ Volume of brine required to saturate the column.

Original oil in place $($ OOIP $)(\mathrm{mL})=$ Amount of brine solution discharged upon displacement by oil sand pack column.

Initial water saturation $\left(\right.$ Swi \%) $=\frac{X}{P V} \times 100$

Where $\mathrm{X}=$ pore volume- volume of brine displaced after injection of oil in sand pack coloumn.

Residual oil saturation $($ Sor\% $)=\frac{X i}{00 I P} \times 100$

Where $\mathrm{Xi}=$ OOIP- Volume of oil displaced after water flooding

Oil recovery after water flooding $($ Orecwf $)=\frac{\text { Sorwf }}{00 I P} \times 100$

Sorwf $(\mathrm{mL})=$ Oil retained after brine flooding

Sorbf $(\mathrm{mL})=$ Oil released after the feeding of sand pack column saturated with residual oil

Additional oil recovery after bio surfactant flooding $=$ $\frac{\text { oil re cov ered } u \sin g \text { biosurfac } \tan t}{\text { oil in column after water flooding }} \times 100$

\section{Results}

\section{Effect of substrate sources}

In order to optimize the production of BSs from P. chrysogenum SNP5, different substrates such as grease waste, waste cooking oil, soya bean oil and oil cake were used for solid state fermentation and mapped in term of Emulsification Index (EI), Oil Displacement Area in mm (ODA) and drop collapse assay (Figure 1). Although soya bean oil as a substrate had shown high emulsification activity $56 \%$ with oil and $37 \%$ with diesel but grease waste was also found promising alternative due to its low cost and good emulsification activity $43 \%$ with oil and $22 \%$ with diesel.

Growing on waste cooking oil where displaced oil on a water surface was $5 \mathrm{~cm}$ without displaying very effective emulsification. Biosurfactant produced over grease waste and wheat bran displaced the oil $(3.5 \mathrm{~cm})$ and shown a good destabilization of surfactant drop on an oil coated glass surface.

\section{Effect of nitrogen sources}

Different nitrogen sources like $\mathrm{NaNO}_{3}$, yeast extract, peptone and malt extract were used and observed that yeast and $\mathrm{NaNO}_{3}$ were growth as well as production promoting (Table 2). Other complex sources like peptone and malt extract were good for growth but not suitable for BS production.

\section{Effect of substrate ratio}

Grease waste in different ratio with wheat bran $\left(\mathrm{NaNO}_{3}\right.$ as a constant nitrogen source) shows an effective change in emulsification index and oil displacement activity as observed in Table 3. The best value of emulsification index and oil Displacement activity was detected at 1.5:1 ratio of grease and wheat bran respectively. A significant decrease in activity of BS was observed as the ratio of grease waste was increased 


\begin{tabular}{|c|c|c|c|c|}
\hline Nitrogen (1\%) & $\begin{array}{c}\text { El (oil) } \\
(\text { \%) }\end{array}$ & $\begin{array}{c}\text { El( diesel) } \\
(\%)\end{array}$ & ODA (cm) & DCA \\
\hline $\mathrm{NaNO}_{3}$ & $43 \pm 0.15$ & $22 \pm 0.09$ & $3 \pm 0.15$ & ++ \\
\hline Peptone & $40 \pm 0.10$ & $20 \pm 0.12$ & $3 \pm 0.01$ & ++ \\
\hline Yeast & $45 \pm 0.61$ & $23 \pm 0.13$ & $4 \pm 0.75$ & +++ \\
\hline malt & $37 \pm 0.23$ & $17 \pm 0.21$ & $2 \pm 0.93$ & + \\
\hline
\end{tabular}

Table 2: Influence of nitrogen content (1\%) for biosurfactant production in terms of El: Emulsification Index; ODA: Oil Displacement Assay; DCA: Drop Collapse Assay; (+: less dispersed drop; ++: moderate dispersed drop; +++ highly dispersed drop of surfactant).

\begin{tabular}{|c|c|c|c|c|}
\hline $\begin{array}{c}\text { Substrate concentration } \\
\text { (Wheat bran and grease ratio) }\end{array}$ & $\begin{array}{c}\text { El (oil) } \\
(\mathbf{\%})\end{array}$ & $\begin{array}{c}\text { El(diesel) } \\
\text { (\%) }\end{array}$ & ODA (cm) & DCA \\
\hline $1: 1$ & $43 \pm 0.30$ & $22 \pm 0.07$ & $3 \pm 0.17$ & ++ \\
\hline $1.5: 1$ & $45 \pm 0.06$ & $24 \pm 0.01$ & $4 \pm 0.30$ & +++ \\
\hline $2: 1$ & $43 \pm 0.10$ & $18 \pm 0.50$ & $2 \pm 0.2$ & ++ \\
\hline $2.5: 1$ & $40 \pm 0.22$ & $18 \pm 0.03$ & $1 \pm 0.72$ & + \\
\hline $3: 1$ & $37 \pm 0.13$ & $15 \pm 0.04$ & $1 \pm 0.51$ & + \\
\hline
\end{tabular}

Table 3: Effects of substrate ratio for biosurfactant production in terms of El: emulsification index; ODA: Oil Displacement Assay; DCA: Drop Collapse Assay; (+: less dispersed drop; ++: moderate dispersed drop; +++ highly dispersed drop of surfactant)

with constant ratio of wheat bran. Oil displacement results were similar for $\mathrm{NaNO}_{3}$ with Grease and wheat bran (1.5:1) which previously found using grease waste and wheat bran (1:1) ratio with $1 \%$ yeast extract as a nitrogen source.

\section{Effect of $\mathrm{pH}$ on production of BS}

The production of BS was tested over a wide range of $\mathrm{pH}(3-12)$ of medium with wheat bran and grease waste $(1: 1)$ and $1 \% \mathrm{NaNO}_{3}$ as nitrogen source. Growth was observed at all condition but performance of surfactants was observed with significant variations under different pH ranges (Table 4).

Surfactant shows the changes in the activity of emulsion formation in different $\mathrm{pH}$ ranges a positive increase was observed from 2 to 8 (maximum activity with E24, 47.61\% in oil and 38.9\% in diesel (Figure 2) and further some significant reduction was observed from $\mathrm{pH}$ range 8-12.

\section{Foam height analysis:}

Foaming ability of BS was determined $23 \%$ in $10 \mathrm{ml}$ crude surfactant. To improve this observation further stability of foam was continuously monitored after every 5 minutes for $1 \mathrm{hr}$ and after 1 hour $3 \%$ reduction was found in initial foam height $(2 \mathrm{~m})$ (Figure 3 ).

\section{Effect of solvent system for extraction of BS:}

Another aspect which was fundamental to analysis of suitable solvent for collection of cell free extracts (a source of crude BS) from fermented bran was application of various buffers ( $\mathrm{pH} 3-10)$ and their comparative study with water as a solvent system. It was observed that all buffer system was depicted as week solvent comparative to water for BS extraction. Obtained results were shown the dependency of emulsification activity with various buffer ranges. It is clearly observed that emulsification activity was gradually increased from $\mathrm{pH}$ (3-7) then it was again expressed reduction but overall it cumulative effects was very low compare to water as a solvent with maximum activity $43 \%$ in case of oil and $22.06 \%$ in case of hydrocarbon (Table 5).

\section{Analysis through thin layer chromatography:}

Characterization of BS collected by precipitation method was determined by TLC method. A red color spot was observed after the use of ninhydrin reagent and a yellow color spot was developed by iodine vapors with a $\mathrm{Rf}$ value $0.69,0.69,0.73$ respectively in soya bean oil, grease and waste cooking oil. Presence of red color in ninhydrin with $\mathrm{Rf}$ values $0.62,0.68,0.66$ respectively in soya bean oil, grease and waste cooking oil, confirms presence of protein and yellow spot with iodine confirmed the lipid moiety of surfactant (Figure 4).

\section{Lowery assay}

Protein concentration of surfactant was determined through lowery assay [18]. In $1 \mathrm{mg}$ of partially purified BS the protein concentration was $13 \%(0.13 \mathrm{mg} / \mathrm{ml})$

\begin{tabular}{|c|c|c|c|c|}
\hline pH range & El (oil) (\%) & El (diesel) (\%) & ODA (cm) & DCA \\
\hline 3 & $37 \pm 0.09$ & $14 \pm 0.28$ & $2.2 \mathrm{~cm}$ & + \\
\hline 4 & $40 \pm 0.05$ & $19 \pm 0.04$ & $3.3 \mathrm{~cm}$ & + \\
\hline 5 & $4 \pm 0.30$ & $22 \pm 0.07$ & $3.9 \mathrm{~cm}$ & ++ \\
\hline 6 & $45 \pm 0.03$ & $23 \pm 0.80$ & $4.1 \mathrm{~m}$ & ++ \\
\hline 7 & $45 \pm 0.09$ & $23 \pm 0.9$ & $4.8 \mathrm{~cm}$ & +++ \\
\hline 8 & $47 \pm 0.61$ & $38 \pm 0.09$ & 5.5 & +++ \\
\hline 9 & $45 \pm 0.07$ & $30 \pm 0.45$ & 5.3 & ++ \\
\hline 10 & $44 \pm 0.10$ & $25 \pm 0.03$ & 4.7 & ++ \\
\hline 11 & $43 \pm 0.01$ & $18 \pm 0.18$ & 4.1 & ++ \\
\hline 12 & $38 \pm 0.09$ & $15 \pm 0.03$ & 3.4 & + \\
\hline
\end{tabular}

Table 4: Influence of different $\mathrm{pH}$ values for production of biosurfactant in terms of El: Emulsification Index; ODA: Oil Displacement Assay; DCA: Drop Collapse Assay; (+: less dispersed drop; ++: moderate dispersed drop; +++ highly dispersed drop of surfactant).

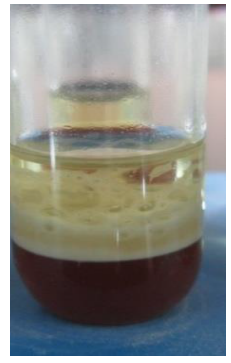

$2 a$

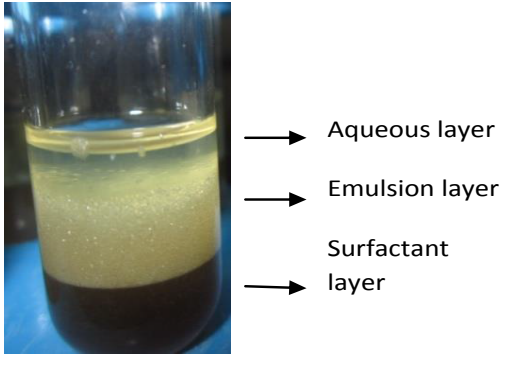

$2 b$
Figure 2: Emulsion formation. 2a: emulsion formation in presence of diesel and surfactant. $\mathbf{2 b}$ : emulsion formation in presence of oil and surfactant

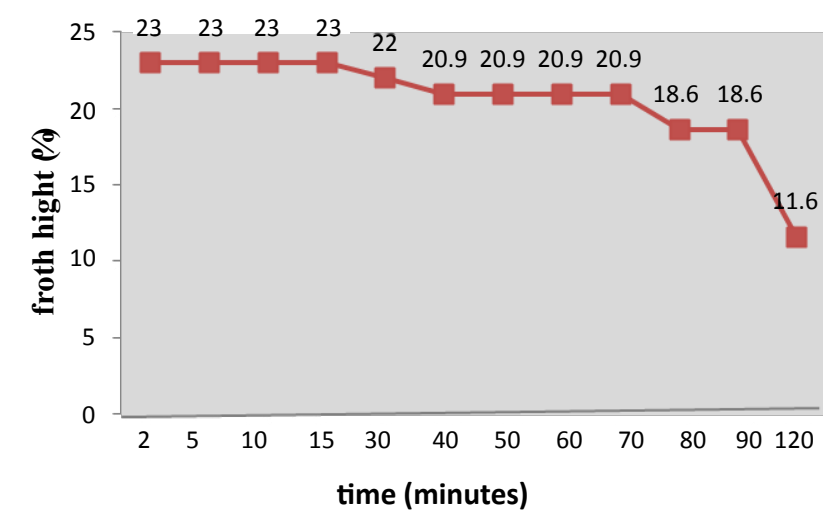

Figure 3: Foam height in \% after various time intervals (2-120 minutes). 


\begin{tabular}{|l|c|c|c|c|}
\hline Solvent system & El ( oil) (\%) & El( diesel) (\%) & ODA (in cm) & DCA \\
\hline Sodium citrate buffer 3 & $27 \pm 0.11$ & $9 \pm 0.17$ & $1 \pm 0.40$ & + \\
\hline Sodium citrate buffer- 4 & $28 \pm 0.20$ & $10 \pm 0.30$ & $1 \pm 0.1$ & + \\
\hline Sodium citrate buffer 5 & $30 \pm 0.05$ & $12 \pm 0.51$ & $0 \pm 0.95$ & + \\
\hline Sodium citrate buffer 6 & $33 \pm 0.12$ & $13 \pm 0.61$ & $1 \pm 0.70$ & + \\
\hline sodium carbonate buffer 7 & $35 \pm 0.19$ & $15 \pm 0.21$ & $2 \pm 0.4$ & + \\
\hline sodium carbonate buffer 8 & $29 \pm 0.05$ & $12 \pm 0.05$ & $1 \pm 0.05$ & + \\
\hline sodium carbonate buffer9 & $19 \pm 0.01$ & $10 \pm 0.02$ & nd & nd \\
\hline sodium carbonate buffer 10 & $13 \pm 0.08$ & $8 \pm 0.14$ & nd & nd \\
\hline Water & $43 \pm 0.31$ & $22 \pm 0.06$ & $3 \pm 0.19$ & ++ \\
\hline
\end{tabular}

Table 5: Optimization of different solvent system for extraction of biosurfactant from fermented substrate in terms of El: Emulsification Index; ODA: Oil Displacement Assay; DCA: Drop Collapse Assay; (+: less dispersed drop; ++: moderate dispersed drop; +++ highly dispersed drop of surfactant).

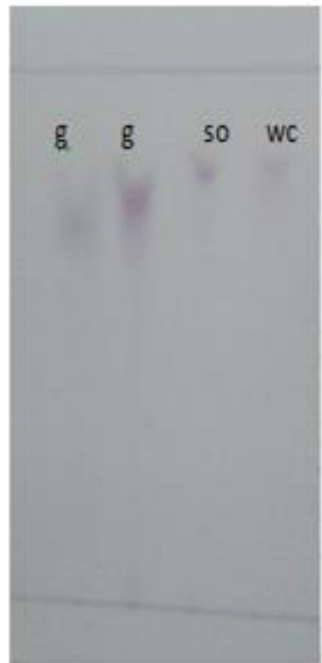

$4 a$

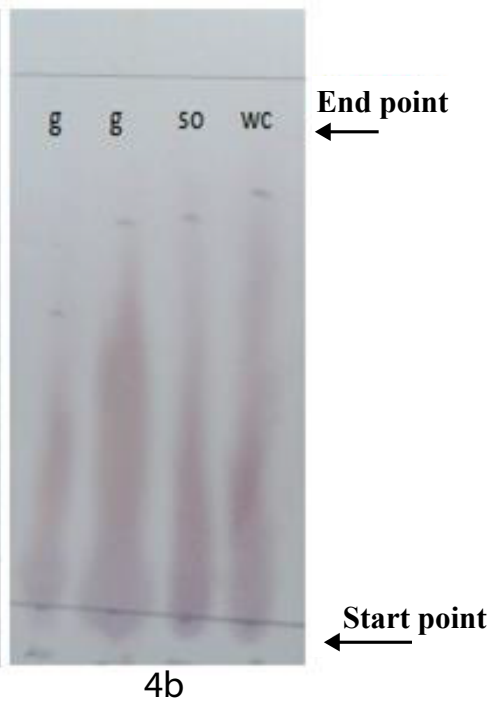

Figure 4a: TLC of partially purified biosurfactant produced by grease (g), soyabean oil (SO) and Waste cooking oil (wc). 4b: TLC of crude biosurfactant produced by grease (g), soyabean oil (SO) and Waste cooking oil (wC).

\section{FTIR analysis}

The FTIR spectra of partially purified BS are shown in figure 5. Characterization absorption peak were found at $3398 \mathrm{~cm}^{-1}$ ranging from $3100 \mathrm{~cm}^{-1}$ to $3600 \mathrm{~cm}^{-1}$. This feature typically confirmed presence of carbon and amino groups and caused due to stretching vibrations of $\mathrm{C}-\mathrm{H}$ and $\mathrm{N}-\mathrm{H}$ bonds characterized to carbon containing amino group. Two other sharp bands at $2926 \mathrm{~cm}^{-1}$ and $2850 \mathrm{~cm}^{-1}$ showed presence of long alkyl chain $\left(-\mathrm{CH}_{2}-\right.$ and $\left.-\mathrm{CH}_{3}-\right)$. The medium band near $1637 \mathrm{~cm}^{-1}$ attributed to $\mathrm{CO}-\mathrm{NH}$ bend which confirms presence of peptide group in the 286 molecule. Other significant peaks observed at $1384 \mathrm{~cm}^{-1}$ correspond to $\mathrm{C}-\mathrm{H}$ vibrations. A medium stretch peak around 1084 $\mathrm{cm}^{-1}$ signifies to presence of C-O-C stretch of ester. And at last a sharp peak at the region around $669 \mathrm{~cm}^{-1}$ and $770 \mathrm{~cm}^{-1}$ also represented $-\mathrm{CH}-$ bending of alkenes.

\section{Antimicrobial activity of BS}

The results of antimicrobial activity of lipopeptide produced by $P$. chrysogenum SNP5 against pathogenic bacteria $S$. aureus and $P$. aeruginosa are shown in table 6 . Presence of clear halos indicating that antimicrobial activity of the compound against gram +ve (S. aureus) and gram-ve ( $P$. aeruginosa) bacteria with a hallo diameter of mean values $1.67 \mathrm{~cm}$ and $1.93 \mathrm{~cm}$ respectively (Table 6).

\section{Application of BS for oil recovery}

While applying 0.6 pore volume of cell free BS to the oil saturated sand column, to recover oil trapped (43.2\%) in the column, $16.5 \pm 2$ AOR was achieved upon $24 \mathrm{~h}$ of incubation (Table 7 ).

\section{Discussion}

On the basis of results obtained in current study it can be stated that production of BS through solid state fermentation is much advantageous than submerged fermentation. Especially in case of BS where SSF emphasize to less energy and cost requirement and very important foaming nuisance in fermentation system, which generally found as drawback in Submerged Fermentation (SmF). Various types of strains of bacteria and fungus have been reported for the efficient production of secondary metabolites under SSF by many scientists [21-24].

In present work production and effectiveness of BS was tried to enhance through optimizing various physiochemical conditions and selecting appropriate media for SSF. However results were promising using wheat bran and soybean oil (emulsification activity $56 \%$ with oil and $37 \%$ with diesel) but for further study wheat bran and grease waste (emulsification activity $43 \%$ with oil and $22 \%$ with diesel) was considered in order to find out good alternative tool for remediation of oil spills and hydrocarbon contaminated soil sites etc. By using hydrocarbon based grease waste as substrate for production, BS produced might be specific for petroleum products removal or

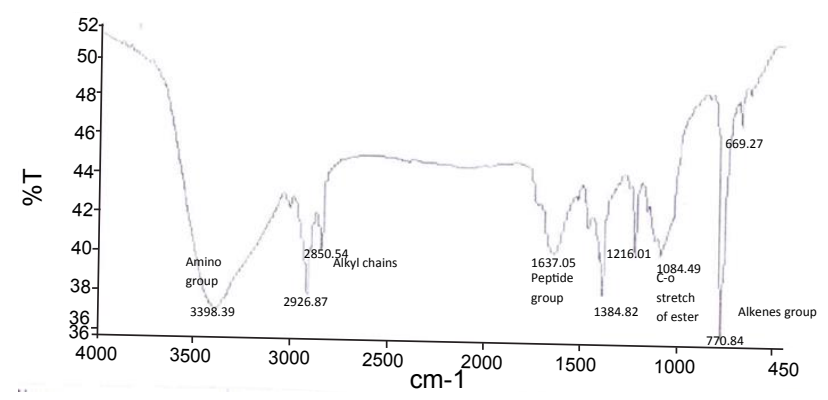

Figure 5: FTIR spectra of partially purified biosurfactant.

\begin{tabular}{|c|c|c|c|c|c|}
\hline S.No. & Name of strain & \multicolumn{3}{|c|}{ Zone of inhibition $\mathbf{( c m )}$} & Mean value \\
\hline 1 & S. aureus & 1.8 & 1.6 & 1.6 & 1.67 \\
\hline 2 & P. aeruginosa & 2 & 1.8 & 2.0 & 1.93 \\
\hline
\end{tabular}

Table 6: Antimicrobial activity with partially purified biosurfactant.

\begin{tabular}{|c|c|c|c|}
\hline \multirow{2}{*}{ Parameters } & \multicolumn{3}{|c|}{ Sand Pack Column (SPC) } \\
\cline { 2 - 4 } & SPC1 & SPC2 & SPC3 \\
\hline PV $(\mathrm{ml})$ & 5.5 & 5.4 & $5.45 \pm 0.70$ \\
\hline OOIP $(\mathrm{ml})$ & 4 & 3.8 & $3.9 \pm 0.14$ \\
\hline Sorwf $(\mathrm{ML})$ & 1.7 & 1.6 & $1.45 \pm 0.70$ \\
\hline Sorfb $(\mathrm{ml})$ & 0.6 & 0.5 & $0.55 \pm 0.70$ \\
\hline Swi $(\%)$ & 72 & 70.3 & $71.15 \pm 1.2$ \\
\hline Soi $(\%)$ & 27 & 29 & $28 \pm 1.4$ \\
\hline Orecwf $(\%)$ & 42 & 44 & $43 \pm 1.4$ \\
\hline AOR $(\%)$ & 18 & 15 & $16.5 \pm 2.1$ \\
\hline
\end{tabular}

Table 7: Parameters for oil recovery using water flood and lipopeptide bio surfactant from sand pack glass column. 
recovery, whereas soybean oil is lipid based. Yeast extract as nitrogen source has shown good impact (displacement of oil is $4 \mathrm{~cm}$ and destabilization of surfactant drop $1.4 \mathrm{~cm}$ compare to water was $0.4 \mathrm{~cm}$ on an oil coated glass surface) on BS production, however $\mathrm{NaNO}_{3}$ was also found enhancer (displacement of oil $3.5 \mathrm{~cm}$ and destabilization of surfactant drop $1.1 \mathrm{~cm}$ in compare to water $0.4 \mathrm{~cm}$ on an oil coated glass surface). Yeast extract being complex and mix kind of nitrogen source might have served as fortifying rather than $\mathrm{NaNO}_{3}$. Selection of substrates and nitrogen sources has major effect on the production of BS $[6,11]$. P. chrysogenum showed different preference on complex and simple nitrogen sources and substrates for BS production [4].

While optimizing the ratio of Wheat Bran (WB) and grease waste for production it was observed that with increase ratio of Grease Waste (GW), emulsification activity reached up to $45 \%$ with oil and $24 \%$ with diesel at a ratio of $1.5: 1 \mathrm{w} / \mathrm{w}$ of grease waste and wheat bran respectively without use of other complex nitrogen sources. But with more than this ratio reduction in emulsification index and oil displacement activity from $22-15 \%$ and $3-1 \mathrm{~cm}$ respectively was observed due to its complexity in nature and hard to utilize completely.

Use of various buffer as a solvent systems showed high impact over recovery of crude BS and found water as best solvent in compare to other solvents. Similar findings were also observed by other scientist [22]. However, in this study the optimization of BS production was confirmed through some indirect methods like Emulsification index, Oil displacement assay and Drop collapse. These are very sensitive and effective methods to confirm the production of BS $[11,23]$. Abouseoud, et al. [11] had optimized the carbon source, nitrogen source and $\mathrm{C} / \mathrm{N}$ ratio for bio surfactants production on the basis of emulsification index [11]. In similar manner bio surfactant production optimization was reported by Kiran et al. [23], where optimization of BS production by Nocardiopsis lucentensis MSA04 with various carbon sources in solid-state cultivation had been performed by using Emulsification index reported of about E24=25\% with wheat bran as substrate [23]. Colla et al. [24] have studied simultaneous production of lipases and BSs by submerged and solid-state bioprocesses with a fungal strain Aspergillus sp. and they reported that the production of BS was very low in SSF (emulsification activity after 24 hours was 2.85\%) compare to $\mathrm{SmF}$ (emulsification activity after 24 hours was $42.67 \%$ ). Therefore this current study with $P$. chrysogenum SNP5 by using grease waste as substrate for BS production with their optimized emulsification value $43 \%$ would be a good benchmark among already reported BSs and also can be accentuate Solid state cultivation of BSs production. And using grease waste as substrate for production make the process cost effective, sustainable and innovative.

BS obtained after extraction was precipitated out and characterized through thin layer chromatography. Results confirmed that BS produced by $P$. chrysogenum SNP5 by using grease waste as substrate was lipopeptide in nature. Presence of peptide and lipid was confirmed on the basis of Rf value 0.68 and 0.69 obtained with ninhydrin and iodine respectively during TLC.

Earlier study confirmed the TLC data with the Rf value of 0.68 and 0.70 for lipopeptide in case of iodine treatment [25] and in case of lipopeptide isolated from Kocuria marina BS-15 also confirmed $\mathrm{Rf}$ value 0.68 [26]. It was again verified from FTIR spectrum of BS which has shown vibration at $2926 \mathrm{~cm}^{-1}$ and $2850 \mathrm{~cm}^{-1}$ and $1384 \mathrm{~cm}^{-1}$ suggested the presence of aliphatic chain of fatty acids, at $3398 \mathrm{~cm}^{-1}$ indicating presence of $\mathrm{C}-\mathrm{H}$ and $\mathrm{N}-\mathrm{H}$ bonds stretching of peptides. A vibration near $1647 \mathrm{~cm}^{-1}$ showed the presence of $\mathrm{CO}-\mathrm{NH}$ bond and vibration near $1084 \mathrm{~cm}^{-1}$ signified presence of $\mathrm{C}-\mathrm{O}-\mathrm{C}$ stretch of ester.
The FTIR analysis was quite similar to result obtained by Thavasi et al. [27] They found spectra at 2,852, 2,923,1,421, and $1,465 \mathrm{~cm}^{-1}$ for the $\mathrm{C}-\mathrm{H}$ stretching mode. 3,383 and $1,647 \mathrm{~cm}^{-1}$ for $\mathrm{C}-\mathrm{O}$ and $\mathrm{N}-\mathrm{H}$ vibration and the $\mathrm{C}-\mathrm{O}$ ester bonds were observed at $1,058 \mathrm{~cm}^{-1}$ [27].

Surfactant produced by $P$. chrysogenum SNP5 was lipopeptide in nature, hence $\mathrm{pH}$, solvent and buffer have shown high impact on its activity, stability and emulsification efficiency etc. due to presence of free $\mathrm{NH}, \mathrm{C}=\mathrm{O}$ and $\mathrm{COOH}$ group. It can be characterized further for its molecular structure in detail.

Lipopeptides are commercially known for their antimicrobial activity against Multi Drug Resistance (MDR) strains [20]. The partially purified lipopetide was shown good antimicrobial activities of $1.67 \mathrm{~cm}$ and $1.93 \mathrm{~cm}$ against gram +ve (S. aureus) and gram -ve ( $P$. aeruginosa) respectively. This is little contrasting to previous reports where lipopeptides have been reported mostly against gram +ve bacteria [28]. The current scenario of pathogenic strain against drug resistance depends upon indiscriminate use of regular common antibiotics. Both strain are a very common example of MDR and generally show resistance against Methicillin and Streptomycin. Hence these new lipopeptide produced from $P$. chrysogenum SNP5 can gives an alternative to already existing antimicrobial drugs [6]. So finally BS produced due to its light molecular weight and lipopeptide in nature would be most desirable and useful in food, pharmaceutical like, medicine, agriculture industries and for bioremediation purpose like oil tanks clean up [29-31].

BS produced as crude extract was also tested for it application in oil recovery which is very challenging and costly efforts in petroleum and oil industries. And it was found very efficient even in crude form for recovery of trapped oil in column. Hence could be very useful in petroleum and oil industries, also it can be applied for pipeline washing due to its both the properties i.e., antimicrobial property to check microbial corrosion and surface activity for washing out retained oil from the surface.

\section{Conclusion}

In present study SSF using grease waste as substrate for BS production had been found promising due to its cost effectiveness and single step downstream processing. BS produced had shown an effective emulsification and oil displacement activity against crude oil as well as it has shown a potential antimicrobial activity also. Therefore, BS produced may be utilized towards the solid waste management, in oil recovery and in food processing. The BS produced by $P$. chrysogenum SNP5 was characterized as lipopeptide derivative, which is different from the liposaccharide BS produced by $P$. citrium, reported by Demorais et al. [15] and finally create a potential alternative over the various other chemical surfactants. Now a day's solid waste management is a critical issue and this strain or its surface active compounds can be used as a good alternative for biostimulation or bioagumentation respectively. Further study may open new horizon for industries.

\section{Acknowledgement}

Authors are thankful to, Technical Education Quality Improvement Programme, India and Department of Science and Technology, Government of India for providing facility and resources for current work. Author declared no conflict of interest.

\section{References}

1. Rahman PKSM, Gakpe E (2008) Production, characterization and applications of biosurfactants-Review. Biotechnology 7: 360-370. 
Citation: Gautam G, Mishra V, Verma P, Pandey AK, Negi S (2014) A Cost Effective Strategy for Production of Bio-surfactant from Locally Isolated Penicillium chrysogenum SNP5 and Its Applications. J Bioprocess Biotech 4: 177 doi: 10.4172/2155-9821.1000177

2. Ron EZ, Rosenberg E (2002) Biosurfactants and oil bioremediation. CurrOpin Biotechnol 13: 249-252.

3. Kosaric N (1992) Biosurfactants in industry. Pure \& Appl Chem 64: 1731-1737

4. Makkar RS, Cameotra SS (2002) An update on the use of unconventional substrates for biosurfactant production and their new applications. App Microbiol Biotechnol 58: 428-434.

5. Transparency market research (2012) Biosurfactant Market- Global scenario, raw material and consumption trends industry analysis, size, share and forecast, 2011-2018.

6. Das P, Mukherjee S, Sen R (2008) Antimicrobial potential of a lipopeptidebiosurfactant derived from a marine Bacillus circulans. J Appl Microbiol 104: 1675-1684.

7. Shaligram NS, Singhal RS (2010) Surfactin - A Review on Biosynthesis, Fermentation, Purification and Applications. Food Technol Biotechnol 48: 119-134.

8. Krieger N, Camilios Neto D, Mitchell DA (2010) Production of microbial biosurfactants by solid-state cultivation. Adv Exp Med Biol 672: 203-210

9. Satpute SK, Bhuyan SS, Pardesi KR, Mujumdar SS, Dhakephalkar PK, et al (2010) Molecular genetics of biosurfactant synthesis in microorganisms. Adv Exp Med Biol 672: 14-41.

10. Kumar S, Katiyar N, Ingle P, Negi S (2011) Use of evolutionary operation (EVOP) factorial design technique to develop a bioprocess using grease waste as a substrate for lipase production. Bioresour Technol 102: 4909-4912.

11. Abouseoud M, Maachi R, Amrane A, Boudergua S, Nabi A (2008) Evaluation of different carbon and nitrogen sources in production of biosurfactant by Pseudomonas fluorescens. Desalination 223: 143-151.

12. Walter V, Syldatk C, Hausmann R (2010) Screening concepts for the isolation of biosurfactant producing microorganisms. Adv Exp Med Biol 672: 1-13.

13. Violeta O, Oana S, Matilda C, Maria CD, Catalina V, et al. (2011) Production of biosurfactants and antifungal compounds by new strains of Bacillus Spp. isolated from different sources. Rom Biotechnol Lett 16: 84-91.

14. El- Shesthawy HS, Doheim MM (2014) Selection of Pseudomonas aeruginosa for biosurfactant production and studies of its antimicrobial activity. Egyptian Journal of Petroleum 23: 1-6.

15. De-Morais MMC, Ramos SAF, Pimental MCB, Melo EHM, Morais MA, et al (2006) Liposaccharide extracellular emulsifier produced by Penicilliumcitrinum Journal of Biological Sciences 6: 511-515.

16. Carrillo PG, Mardaraz C, Pitta-Alvarez SI, Giulietti AM (1996) Isolation and selection of biosurfactant-producing bacteria. World J Microbiol Biotechnol 12: 82-84

17. Symth TJP, Permuo A, McClean S, Marchant R, Banat IM (2010) Isolation and
Analysis of Lipopeptides and High Molecular Weight Biosurfactants: Handbook of Hydrocarbon and Lipid Microbiology. ( $5^{\text {th }}$ edition), springer, Berlin, Heidelberg.

18. Lowry OH, Rosebrough NJ, Farr AL, Randall RJ (1951) Protein measurement with the Folin phenol reagent. J Biol Chem 193: 265-275.

19. Mukherjee S, Das P, Sen R (2006) Towards commercial production of microbial surfactants. Trends Biotechnol 24: 509-515.

20. Rodrigues L, Banat IM, Teixeira J, Oliveira R (2006) Biosurfactants: potential applications in medicine. J Antimicrob Chemother 57: 609-618.

21. Negi S, Kumar S (2012) Evaluation of techniques used for parameters estimation: an application to bioremediation of grease waste. Appl Biochem Biotechnol 167: 1613-1621.

22. Kitamoto D, Ikegami T, Suzuki GT, Sasaki A, Takeyama Y, et al.(2001) Microbia conversion of $n$-alkanes into glycolipid biosurfactants, mannosylerythritol lipids, by Pseudozyma (Candida antarctica). Biotechnol Lett 23: 1709-1714.

23. Kiran GS, Thomas TA, Selvin J (2010) Production of a new glycolipid biosurfactant from marine Nocardiopsis lucentensis MSA04 in solid-state cultivation. Colloids Surf B Biointerfaces 78: 8-16.

24. Colla LM, Rizzardi J, Pinto MH, Reinehr CO, Bertolin TE, et al. (2010) Simultaneous production of lipases and biosurfactants by submerged and solid-state bioprocesses. Bioresour Technol 101: 8308-8314.

25. Anyanwu CU, Obi SKC, Okolo BN (2011) Lipopeptide biosurfactant production by Serratia marcescens NSK-1 strain isolated from petroleum-contaminated soil. Journal of Applied Sciences Research 7: 79-87.

26. Sarafin Y, Donio MBS, Velmurugan S, Michaelbabu M, Citarasu T (2014) Kocuria marina BS-15 a biosurfactant producing halophilic bacteria isolated from solar salt works in India. Saudi Journal of Biological Sciences. In Press.

27. Thavasi R, Subramanyam Nambaru VR, Jayalakshmi S, Balasubramanian T, Banat IM (2009) Biosurfactant production by Azotobacter chroococcum isolated from the marine environment. Mar Biotechnol (NY) 11: 551-556.

28. Singh P, Cameotra SS (2004) Potential applications of microbial surfactants in biomedical sciences. Trends Biotechnol 22: 142-146.

29. Banat IM, Samarah N, Murad M, Horne R, Banerjee S (1991) Biosurfactant production and use in oil tank clean-up. World J Microbiol Biotechnol 7: 80-88.

30. Bhadauriya SS, Madoriya N, Shukla K, Parihar MS (2013) Biosurfactants: A new pharmaceutical additive for solubility enhancement and pharmaceutical development. Biochem Pharmacol 2: 113.

31. Colin VL (2012) Technology of biosurfactants for the development of environmental remediation processes. Ferment Technol 1: e109. 